\title{
INTERPRETAÇÃO SÍSMICA E MODELAMENTO MAGNETOMÉTRICO E GRAVIMÉTRICO 2D E 3D DE CORPOS VULCÂNICOS LOCALIZADOS NA SUB-BACIA DO PLATÔ DE PERNAMBUCO - UMA CONTRIBUIÇÃO À SUA EVOLUÇÃO TECTONO-ESTRATIGRÁFICA
}

\author{
Edlene Pereira da Silva \\ Orientador: Dr. Paulo de Barros Correia (UFPE) \\ 101 p. - Dissertação (Mestrado) - Defesa 05.09.2008
}

\begin{abstract}
RESUMO. A Sub-bacia do Platô de Pernambuco é uma das últimas porções sedimentares percebidas e descritas na literatura, e certamente uma das últimas a ser formada durante a separação das placas Sul-Americana e Africana. Ela corresponde à sub-bacia offshore da Bacia de Pernambuco e é marcada por grande proporção de derrames vulcânicos ocasionados provavelmente por essa estar assentada sobre porção de crosta continental distendida, o que favorece a ascensão do material magmático em pulsos tectônicos relacionados à fase de abertura do Atlântico, quando se deu a formação da Bacia de Pernambuco. Estudos Geofísicos envolvendo Magnetometria e Gravimetria posicionam estratigraficamente e estruturalmente os corpos magmáticos que ocorrem na área, sugerindo formas e proporções atingidas pelos mesmos, através de análise de mapas confeccionados e dos modelos gerados (2D e 3D). Após criteriosa seleção das linhas sísmicas mais interessantes do ponto de vista dos corpos magmáticos, foco desta pesquisa, estas foram testadas também por modelos gravimétricos e magnéticos. Os métodos foram trabalhados separadamente, integrando-se inicialmente os resultados dos métodos potenciais e, depois, obteve-se a integração final dos três métodos estudados, a qual forneceu elementos elucidativos que conduziram a conclusões sobre o posicionamento tectono-estratigráfico desses corpos e suas caracterizações, como possível origem relacionada à pluma do manto e limites entre a crosta continental e oceânica mostrados em mapas (gravimétricos e magnéticos). Estes limites são atribuídos ao crescimento das ocorrências de injeções de intrusões magmáticas, o que é assinalado na literatura como ocorrências de SDRs ( Seaward Dipping Reflectors). 0 maior dos derrames de rochas vulcânicas observado corresponde à maior anomalia magnética da Sub-Bacia do Platô de Pernambuco, sendo também facilmente detectado pela sísmica e gravimetria. Trata-se de um corpo posicionado na região central desta sub-bacia que apresenta dimensões gigantescas e uma forte expressão batimétrica.
\end{abstract}

ABSTRACT. The Pernambuco Plateau Sub-basin is one of the last sedimentary portions ever found and described in literature, and certainly one of the last formed when the South-American and South-African continental plates went adrift from each other. It correlates to the offshore sub-basin from Pernambuco Basin and is marked by vast volcanic flows probably caused by its standing over that tensioned continental crust portion, which in turn might favor magmatic material ascension in tectonic pulses, related to the opening of the Atlantic Ocean, when the Pernambuco Basin itself was formed. Geophysical studies involving Magnetometry and Gravimetry methods pinpoint stratigraphically the magmatic bodies that occur in that area, suggesting shapes and proportions achieved by such bodies through map analysis and 2D-3D correlation models. After rigorous selection of the most interesting seismic lines from the viewpoint of magmatic bodies which are the target of this research, they were tested by means of gravimetric, seismic and magnetic models. The three methods were used separately, initially integrating the results of potential methods achieving their final integration afterwards, which gave elucidative elements that led to conclusions about tectonic-stratigraphic positioning and features of those bodies, such as their possible origin from a mantle plume and the limits between the continental crust and oceanic crust, shown in both gravimetric and magnetic maps. These limits are thought to come from a rise in seaward-dipping reflection occurrences. The biggest volcanic rock flow among the ones we observed correlates to the biggest magnetic anomaly in the Pernambuco Plateau Sub-basin, also being easily detected by seismicity and gravimetry. This is a body positioned at the core region of the sub-basin, which shows huge dimensions and a strong batimetric signature. 